\title{
Rättssäker examination i ny upplaga
}

\author{
Tobias Hägerland* \\ Lunds universitet
}

\begin{abstract}
Universitetskanslersämbetets vägledning Rättssäker examination utkom 2017 i sin tredje upplaga. I denna kommentar uppmärksammas några av de nya anvisningarna. Dessutom diskuteras ett antal punkter som skulle kunna beröras i nästa utgåva av vägledningen.
\end{abstract}

Nyckelord: examination, högskolejuridik, högskolepedagogik, rättssäkerhet

\section{INLEDNING}

Under mina år som studierektor har jag otaliga gånger haft anledning att konsultera rapporten Rättssäker examination, utgiven i sin andra upplaga av dåvarande Högskoleverket (HSV) 2008. När kollegorna hört av sig med frågor om hur olika uppkomna eller tänkbara situationer i samband med examination, bedömning och betygssättning ska hanteras har jag ofta sänt en tacksamhetens tanke till de juridiska experter som åstadkommit denna ovärderliga sammanställning av vad lagar, förordningar och myndighetens yttranden har att säga om hur examination i vid mening ska genomföras vid svenska lärosäten. Som bekant är högre utbildning en föränderlig värld, och de ställningstaganden som gjordes för närmare ett decennium sedan är inte alltid längre aktuella eller heltäckande. Därför är Universitetskanslersämbetets (UKÄ) nya, tredje upplaga (2017) av det som nu med rätta kallas för en "vägledning" efterlängtad och välkommen.

I likhet med de tidigare upplagorna av Rättssäker examination baseras den tredje utgåvan i första hand på gällande författningar, $\mathrm{i}$ andra hand på de olika yttranden som myndigheten gjort i samband med tillsynsärenden och $\mathrm{i}$ tredje hand på rådande praxis vid universitet och högskolor. Utvalda institutioner, liksom lärosätenas ledningar och Sveriges förenade studentkårer (SFS), har fått besvara frågor och lämna synpunkter under revideringsarbetet. En av vägledningens starka sidor är just respekten för etablerad praxis så länge denna är förenlig med lag och förordning. Ställningstagandena uttrycker ingen tendens till övernitiskt paragrafrytteri utan håller tvärtom, på det hela taget, en god balans mellan å ena sidan månandet om rättssäkerhetsidealet och å andra sidan förståelsen för att universitetslärarnas professionella uppdrag att examinera kräver ett visst mått av frihet och flexibilitet. Symptomatisk är slutsatsen i avsnittet "Hur får prov utformas?" (s. 49-50), som är en utveckling av andra upplagans avsnitt "Vad får tentamensfrågorna avse?". Här nämns att UKÄ ibland får frågor från studenter både om vad som "får komma på tentan" och om hur prov får "läggas upp". Myndighetens besked är att författningarna inte anger några begränsningar vare sig för vilka frågor som får ställas vid ett provtillfälle, så länge dessa hänför sig till kursmålen, eller för hur proven ska vara konstruerade: "Lärosätena har alltså stor frihet att utforma prov och andra former av examinationer" (s. 50). Det är en god inställning, som ger förutsättningar för en positiv pedagogisk utveckling av examination och bedömning.

\footnotetext{
*Författarkontakt: Tobias Hägerland, tobias.hagerland@ctr.lu.se

Artiklar och reflektioner är kollegialt granskade. Övriga bidragstyper granskas av redaktionen. Se www.hogreutbildning.se ISSN 2000-7558

(C)2017 Tobias Hägerland. This is an Open Access article distributed under the terms of the Creative Commons Attribution-NonCommercial 4.0 International License (https://creativecommons.org/licenses/by-nc/4.0/), allowing third parties to share their work (copy, distribute, transmit) and to adapt it, under the condition that the authors are given credit, that the work is not used for commercial purposes, and that in the event of reuse or distribution, the terms of this license are made clear.

Citation: Tobias Hägerland (2017) «Rättssäker examination i ny upplaga», Högre utbildning 7, 81-84. http://dx.doi.org/10.23865/hu.v7.956
} 


\section{NÅGRA NYHETER I TREDJE UPPLAGAN}

Vad är då nytt i denna upplaga? En hel del, och här ska bara några exempel ges. Mycket av det som har tillkommit sedan 2008 är inte oväntat. Under rubriken "Anonyma prov" redogör ett stycke för SFS ståndpunkt att sals- och hemtentamina i normalfallet bör vara anonymiserade. UKÄ uttalar tydligare än i förra upplagan "att ett lärosäte vid skriftlig examination bör sträva efter att anordna anonyma prov" men betonar samtidigt att det är "lärosätet som måste avgöra om det är möjligt och lämpligt med anonyma prov på en kurs" (s. 34). En halv sida om "Datorbaserad tentamen" i den andra upplagan har vuxit till det längre avsnittet om "Examination med digitala hjälpmedel" i den tredje (s. 95-98), och ändå aviseras att ämnet ska behandlas mer ingående i nästa utgåva. På några punkter sker viktiga klargöranden i förhållande till tidigare ställningstaganden från HSV. Detta gäller frågan om inom vilka tidsgränser studenter på en kurs måste erbjudas omprov - vissa examinationsformer kräver sådana arrangemang som gör det ytterst svårt, orimligt kostsamt eller omöjligt att erbjuda omprovstillfälle i nära anslutning till ordinarie prov. Här konstaterar UKÄ att "Högskoleverkets uttalanden när det gäller omprov framför allt avsåg traditionell salstentamen och liknande examinationsformer" och att "tidsgränserna för omprov ... inte utan vidare [kan] tillämpas på mer speciella examinationsformer" (s. 78). Ett annat klarläggande avser problematiken med skilda uppfattningar mellan handledare och examinator i samband med examensarbete. Eftersom HSV:s tidigare uttalande om "att det inte bör förekomma att examinatorn kräver mycket omfattande förändringar för att uppsatsen ska kunna godkännas" ibland har kommit "att uppfattas som att studenter har rätt till godkänt betyg om handledaren gett klartecken till uppsatsen", förtydligar UKÄ i anslutning till ett senare tillsynsärende att detta inte är fallet (s. 9I-92). Ytterligare en fråga, som vad jag vet inte tidigare har berörts av HSV/UKÄ men som ibland har gett upphov till stora diskussioner, är om prov får utformas "så att det krävs godkänt på en del av provet eller att studenten fătt ett tillräckligt antal poäng på en viss fråga för att andra delar av provet eller andra frågor ska rättas”. Det bedömer myndigheten som helt förenligt med författningarna (s. 49).

Ett ämne vars aktualitet inte har avtagit, och som ges en betydligt mer ingående behandling $\mathrm{i}$ den nya upplagan, är frågan om examinationsspråk (s. 34-4I). HSV utgick 2008, då den språklag som trädde i kraft året därpå var under beredning, från att regeringen i en särskild reglering skulle klargöra hur andra språk än svenska får användas inom högskolesektorn. Därför tog verket ingen egen ställning i frågan om andra examinationsspråk än svenska. Någon sådan reglering kom inte, och 2017 väljer UKÄ därför att utifrån befintliga författningar tolka läget. Bland annat menar man "att studenter som talar danska eller norska så långt som möjligt bör få använda sina egna språk vid examinationer som hålls på svenska" (s. 4I), vilket är en mer tillåtande hållning än den som kom till uttryck i den andra upplagan. Den kanske mest uppseendeväckande slutsatsen är att studenter i princip alltid ska kunna använda svenska vid examinationen, när det inte strider mot kursmålen: "Enligt UKÄ:s uppfattning kan ett lärosäte inte slentrianmässigt kräva att svar på prov ska lämnas på andra språk än svenska. Det gäller även kurser där undervisning och examination sker på engelska" (s. 38). Min reflektion blir att ansvariga för utbildningar och program, där examensmålen anger att studenten ska kunna kommunicera i internationella sammanhang, behöver vara särskilt uppmärksamma på detta. På sådana utbildningar kan förmågan till muntlig och skriftlig framställning på (exempelvis) engelska behöva skrivas in i själva kursmålen, så att denna kompetens utan undantag examineras. Endast det faktum att man ger kurser på engelska betyder inte att studenternas förmåga att uttrycka sig på detta språk examineras under utbildningen. 
Samma uppmärksamhet är enligt min mening påkallad av ställningstagandet i frågan om anpassad examination (s. 50-52). Detta helt nya avsnitt tar tydlig ställning för att examinatorerna ska ha möjlighet att besluta om anpassade eller alternativa examinationsformer för studenter med funktionsnedsättning. Det kan till exempel handla om att låta en student "komplettera en skriftlig examination med en muntlig examination och vice versa" eller att ersätta en gruppredovisning med en skriftlig examinationsuppgift (s. 5I). UKÄ understryker att denna möjlighet då måste framgå av kursplanen. Även här menar jag att utbildnings- och programansvariga kan behöva se över formuleringarna av lärandemål i kursplanerna, så att både muntliga och skriftliga färdigheter ingår i själva kursmålen och därmed måste examineras. Annars finns risken att examensmålen inte uppfylls, om enskilda examinatorer genom en hel utbildning tillåter att skriftliga examinationsmoment ersätts med muntliga eller vice versa.

\section{FÖRVÄNTNINGAR PÅ FRAMTIDA UPPLAGOR}

I inledningen till den aktuella utgåvan annonseras att en omarbetad upplaga av Rättssäker examination kommer att publiceras under 20I8. Den kommande upplagan ska ta bestämmelserna i den nya förvaltningslagen, som förväntas träda i kraft under nästa år, i beaktande (s. II). Som redan nämnts lovar man också att återkomma med en fördjupad analys av rättssäkerhetsproblemen kring examination med digitala hjälpmedel i "en kommande upplaga av rapporten" (s. 96). Det senare är välkommet. Redan i den andra upplagan nämnde HSV att flera lärosäten hade påpekat att det är svårt att fastställa vem som egentligen har skrivit en hemtentamen. Verket avstod från att yttra sig i frågan med en inte helt övertygande hänvisning till att frågor om fusk inte skulle behandlas i rapporten. I den nya upplagan har inga nya anvisningar kring hemtentamen tillkommit (jfr s. 89), men det verkar alltså som om den tilltagande digitaliseringen har gjort frågan så brännande att den kommer att adresseras i en nära framtid.

Det finns förstås ytterligare frågeställningar och problemområden, som relativt ofta gör sig påminda i den pedagogiska och byråkratiska vardagen, men som inte täcks av vägledningen i den nya upplagan. En sådan fråga gäller salstentor som lämnas in "blanka". Ska de betraktas och registreras som underkända - studenten har ju trots allt påbörjat examinationen - eller ska de över huvud taget inte registreras? Praxis skiljer sig mellan, ibland även inom, lärosätena. Frågan har veterligen inte någon gång tagits upp av tillsynsmyndigheten. En annan gäller relationen mellan obligatoriska utbildningsmoment och examination. UKÄ står fast vid det ställningstagande som gjordes redan i den tidigare upplagan: "När det ... ställs krav på deltagande i ett utbildningsmoment för att studenten ska kunna godkännas på kursen, är det obligatoriska momentet en del av examinationen" (s. 55). Det är inte riktigt tydligt hur myndigheten resonerar här. På annan plats i vägledningen definierar man "examination" som "att en examinator bestämmer ett betyg utifrån den eller de former för bedömning av studenternas prestationer som anges i kursplanen" (s. 25). Måste då en bedömning av studentprestationer äga rum för att ett moment ska kunna göras obligatoriskt? Antagning till och registrering på kursen är ju också nödvändiga förutsättningar för att en student ska kunna godkännas, men naturligtvis inte en del av examinationen. Högskolepedagogisk forskning visar på vikten av att tydligt skilja mellan formativ bedömning (utbildningsinslag där återkoppling ges i syfte att hjälpa studenten till bättre prestation och inte i betygssättande syfte) och summativ bedömning (examination i betydelsen slutbedömning och betygssättning). Min erfarenhet är att många lärare efterfrågar möjligheten att föreskriva närvaro vid vissa tränande moment som inte utgör ett kvalitativt underlag för betygssättningen, men Rätsssäker examination lämnar strikt talat inget utrymme för det. 
En verkligt svårhanterad problematik handlar om examinatorsuppdraget i relation till förhållandet mellan "prov", "del av kurs" och "kurs". Enligt Högskoleförordningen är det normala att examinator sätter betyg "på en genomgången kurs" (6 kap. I8 \$ HF). Rättssäker examination förutsätter en relativt lättöverskådlig situation, där en student registreras på en kurs och examineras på den under ett och samma kurstillfälle av en bemyndigad examinator (s. 24). Verkligheten är betydligt mer komplicerad. Vid lärosätena är det mycket vanligt att betyg sätts på "del av kurs" (i kursplaner ofta benämnt "delkurs" och i Ladok benämnt "prov") och att betyget på hela kursen genereras av delkurs- eller provbetygen i enlighet med vad som står i kursplanen. Den nya upplagan av vägledningen erkänner visserligen detta faktum och nämner "att examinatorer kan behöva utses för såväl delkurserna som för hela kursen" (s. 30), men besvarar inte de följdfrågor som kan uppstå. Om principerna för sammanvägning av delkursbetyg till kursbetyg regleras i kursplanen, blir den examinator som fattar det formella beslutet om betyg på hela kursen bunden av en annan examinators beslut om betyg på en del av kursen. Det kan tyckas komma i konflikt med vägledningens påpekande om att betygsbeslut inte får fattas av flera examinatorer gemensamt (s. 33). Det är inte heller ovanligt att en student examineras och får betyg på en del av kursen, sedan tillfälligt avbryter studierna och återvänder för att slutföra kursen en senare termin. Vid detta senare kurstillfälle är det mycket möjligt att examinator är en annan lärare än den som var examinator då studenten examinerades på den första delen. Annorlunda uttryckt: en del av beredningsstadiet är redan avslutat innan den nya examinatorn har tillträtt sitt uppdrag (jfr s. 44). Samma situation uppstår då en student som har godkänts på en del av kursen beviljas byte av examinator på en senare del av kursen (jfr s. 79-80). Ännu mer komplicerad blir situationen i de - inte sällsynta - fall där merparten av den reella bedömningen av studenternas prestationer vid en institution utförs av visstidsanställda forskare och doktorander, personalkategorier som normalt inte definieras som "lärare" i de lokala anställningsordningarna och som därför inte kan utses till examinatorer (jfr s. 3I). Examinatorsuppdraget förvandlas där ofta till ett rent mekaniskt signerande av stora mängder betygsbeslut utan någon egentlig kvalitetssäkrande funktion. Just här är avståndet mellan den idealvärld som skildras i Rättssäker examination och den verkliga universitetsvärlden synnerligen stort. Det avståndet kan troligen inte överbryggas på annat sätt än genom en genomgripande översyn och revidering av det lapptäcke som gällande högskoleförordning utgör.

\section{AVSLUTNING}

Även om en del frågetecken kvarstår, rätas många ut i den senaste upplagan av Rättssäker examination. Det har varit ett klokt beslut av UKÄ att publicera denna utgåva av vägledningen nu, trots att man förutser en ny revidering redan under 20I8. Jag hoppas och tror att nya upplagor kommer att följa med kortare tidsintervall än hittills, så att examinatorer, utbildningsansvariga och administratörer vid svenska universitet och högskolor fortlöpande har aktuella och lättillgängliga anvisningar för hur det ansvarsfulla uppdraget att examinera ska utföras på ett så korrekt sätt som möjligt. 